\title{
Bokanmeldelse:
}

\section{Om å skrive seg tilbake til livet - sorg og tap som skapende ressurs}

Ved Kari Wille Rekdal

\author{
Elisabeth Endsjф (red): Avtrykk \\ Abstrakt forlag, 2011. 156 sider. \\ ISBN: 978-82-7935-311-9.
}

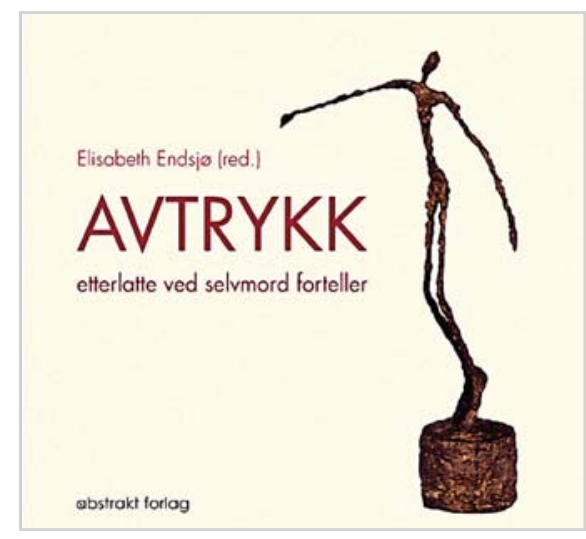

Boka Avtrykk er et resultat av et prosjekt kalt Skapende ressursgruppe for etterlatte ved selumord, og den er gitt ut i samarbeid med blant annet LEVE. Faglig ansvarlig for skriveprosjektet har vært Merete Morken Andersen og Eduardo Verdu. Andersen har lang erfaring som forlagsredaktør og skrivelærer i tillegg til eget forfatterskap, og Verdu er familieterapeut. Hoveddelen av boka er tekster som deltakerne i prosjektet har skrevet, og det er både prosa og lyrikk. Boka inneholder også en fotodagbok som en av deltakerne laget i stedet for å skrive, og Merete Morken Andersen forteller klokt og innsiktsfullt om det å skrive som terapi, og om hvordan arbeidet med å skape som terapi har vært lagt opp. Astri Nøkleby Heiberg har skrevet et forord, og redakt $\varnothing$ r og prosjektleder Elisabeth Endsjø redegjør i kapitlet En sårbar balanse om utgangspunktet for og arbeidet med boka. Resten er de etterlattes stemmer, inkludert et kapittel med en samtale mellom prosjektlederen og tre av de etterlatte.

For å begynne med det ytre: Boka har et sobert og delikat utseende, med Alberto Giacomettis skulptur Falling man som omslagsillustrasjon. Den lange, altfor tynne mannen som nesten ikke henger sammen, er et særdeles velvalgt bilde for bokas tema. Figuren er for lang og for tynn, altfor strukket ut, har ikke riktige proporsjoner til å være et ordentlig menneske, men er allikevel tvers igjennom menneskelig. Avtrykk er også en god tittel; den spiller på alle sidene av de menneskelige relasjonene som inngår i dette prosjektet: Er det tekstene som er avtrykk av noe, er det menneskene som har skrevet dem som lager avtrykk som vi andre kan se, eller er det de som er borte som har satt igjen avtrykk etter seg?

Andersen skriver om hvorfor og hvordan man skal skrive om sine smertelige erfaringer, og hvilken betydning det kan ha både for den som skriver og for den som senere skal lese. Utfordringene er mange og store. For det er ingen automatisk sammenheng mellom det å ha noe å si og det å makte å formidle det på en måte som kan være til nytte eller glede eller trøst for andre. Ressursgruppens ambisjoner for tekstene sine og for boka er nærmest skyhøye:

(...) det var viktig at boka skulle gi håp til andre som har opplevd selumord $i$ familien, eller $i$ andre nære relasjoner. Noen som selv står ved, eller har stått ved, den avgrunnen som et selvmord er. Vi ville lage en bok som kunne vise at det går an å gi slike erfaringer et språk, og giøre dem til en del av seg selv. At det er mulig å romme hele spekteret av sterke og ofte motstridende følelser som det a oppleve et selumord bringer med seg, og fortsatt kunne si at man kan få til et rikt og godt liv. (...) a klare å romme og omdanne smertefulle erfaringer til ressurser som noe nytt kan bli født av. (Andersen i $\AA$ skrive er å plante et frø, s 130)

Fortellingene i boka er delt inn i tre avsnitt, som følger tidsaksen og fasene i tapserfaringen: Sjokket, Sorgen, og Aksept. Alle bidragsyterne greier å formidle til leseren både fasene de gjennomgår og alle følelsene. Om livet som på den ene siden fortsatt er helt vanlig og samtidig aldri blir det samme, om savnet som aldri blir borte, og gledene som allikevel er der etter hvert. Som leser kan man ikke unngå å bli grepet av styrken som formidles, styrken i både sorgen og savnet, men også styrken som den enkelte på ubegripelig vis greier å finne i seg selv. Det som kanskje kommer tydeligst frem, er innsikten om livets mangfold, slik som en av bidragsyterne skriver: Betyr det ikke at livet wårt er en vev med lyse og mørke farger, og at alle fargene hører til $i$ veven?

De etterlattes fortellinger består som nevnt både av prosa og lyrikk. Det vil på den ene siden være urettferdig å anmelde disse tekstene etter vanlige litterære kriterier, på den andre siden fortjener både tekstene og de som har skrevet dem at man tar dem på alvor. Hovedgrunnen til at skriving som egenterapi sjelden blir noe mer enn akkurat det og ikke får noen allmenn betydning, er at tekstene veldig lett blir private. Skillet mellom det private og det personlige er en krevende balansegang. Det private blir fort pinlig og har ingen verdi for andre enn en selv, mens det personlige løfter egenerfaringer over i en sfære som berører alle oss andre også. Som skrivelærer har Andersen klart å få skribentene stort sett til å gi tekstene dette løftet. Som leser savner jeg nok litt variasjon i tekstene; de er alle sammen mer eller mindre refererende og ganske rett frem fortellende. Det er ikke så mange refleksjoner i dem, og det er lite bruk av metaforer og bilder, lite allusjoner, og motivene går rett på tapet og sorgen. Et unntak er fotodagboka til Maria; bildene hennes er stemningsskapende og åpner for refleksjon og fortolkning heller enn direkte å fortelle en historie. Men når det er sagt, så forteller alle deltakerne om sterke, smertefulle erfaringer som vi alle kan ha noe å hente $\mathrm{i}$.

Hvem er denne boka for? Den er selvfølgelig først og fremst for de etterlatte som har vært med og skrevet tekstene. Men alle som har opplevd tap og sorg, vil kunne finne både st $\varnothing$ tte og inspirasjon i boka. Det å lese om andres reaksjoner og erfaringer kan både bekrefte egne reaksjoner som sunne og normale for situasjonen, og det kan gi trøst og håp om at det finnes et liv også etter avgrunnen. Kanskje kan det også inspirere og lære andre å bruke skapende virksomhet som hjelp i sorgarbeidet? Men først og fremst håper jeg at så mange fagpersoner som mulig leser boka og lærer av den. Personer innenfor helsevesenet, mennesker ellers som skal befatte seg med barn og unge, studenter og ansatte; de burde alle sammen kjøpe og lese og bruke denne boka. Vi som er etterlatte, greier ikke å se eller formulere hva slags hjelp vi trenger før etterpå. Vi trenger noen andre som vet, som ikke gir oss en lapp med et telefonnummer, men som aktivt ringer og oppsøker og kommer med konkrete tilbud om hjelpetiltak. For å kunne stille de riktige spørsmålene må fagfolk ha kunnskap om behovene. Og den kunnskapen kan de finne i denne boka, ordsatt av folk som vet hva de snakker om.

Kari Wille Rekdal er jurist, master i nordisk språkvitenskap og sentralstyremedlem i LEVE. 